\title{
Retrieval of the species Alteromonas tetraodonis Simidu et al. 1990 as Pseudoalteromonas tetraodonis comb. nov. and emendation of description
}

\footnotetext{
1 Pacific Institute of Bioorganic Chemistry, Far-Eastern Branch, Russian Academy of Sciences, 690022 Vladivostok pr. 100 let Vladivostok 159, Russia

2 Center of Marine

Biotechnology, University of Maryland Biotechnology Institute, Columbus Center, Suite 236, 701 E. Pratt St, Baltimore, MD 21202, USA

3 School of Public Health, University of Sao Paulo, Av. Dr Arnaldo, 715, Sao Paulo 01246-904, Brazil

4 Institute of Microbiology, Russian Academy of Sciences, 117811 Moscow, Russia

5 Hikarigaoka 5-2-5-806, Nerima-ku, Tokyo 179-0072, Japan

6 Ocean Research Institute, University of Tokyo,

1-15-Minamidai, Nakano-ku, Tokyo 164, Japan

7 Laboratory of Microbiology, Faculty of Fisheries, Hokkaido University, 3-1-1 Minato-cho, Hakodate 041-8611, Japan

8 Institute of Marine Biology, Far-Eastern Branch, Russian Academy of Sciences 690041, Vladivostok, Russia

9 Centre National de la Recherche Scientifique et Université, Pierre et Marie Curie, Station Zoologique, Villefranche-sur-Mer 06230, France

10 Department of Cell Biology and Molecular Biology, University of Maryland, College Park, MD 20742, USA
}

\author{
Elena P. Ivanova, ${ }^{1,2}+$ Ludmila A. Romanenko, ${ }^{1}$ Maria H. Matté, ${ }^{2,3}$ \\ Glavur R. Matté, ${ }^{2,3}$ Anatolii M. Lysenko, ${ }^{4}$ U. Simidu, ${ }^{5}$ K. Kita-Tsukamoto, ${ }^{6}$ \\ Tomoo Sawabe, ${ }^{7}$ Mikhail V. Vysotskii, ${ }^{8}$ Galina M. Frolova, ${ }^{1}$ \\ Valery Mikhailov, ${ }^{1}$ Richard Christen ${ }^{9}$ and Rita R. Colwell ${ }^{2,10}$ \\ Author for correspondence: Elena P. Ivanova. Tel: +6139214 5137. Fax: +6139214 5050. \\ e-mail: eivanova@swin.edu.au
}

A polyphasic taxonomy study was undertaken of three strains of
Pseudoalteromonas haloplanktis subsp. tetraodonis (Simidu et al. 1990) Gauthier et al. 1995. DNA was prepared from each of the strains and genomic relatedness was measured by DNA-DNA hybridization. Strains KMM $458^{\top}$ and IAM $14160^{\top}$ shared $99 \%$ genetic relatedness, but were only $48-49 \%$ related to the type strain of Pseudoalteromonas haloplanktis subsp. haloplanktis, IAM $12915^{\top}$. The third strain, P. haloplanktis subsp. tetraodonis A-M, showed $83 \%$ genetic similarity with $P$. haloplanktis subsp. haloplanktis IAM $12915^{\top}$ and $32 \%$ with KMM 458'. From these results, it is concluded that strains KMM $458^{\top}$ and IAM $14160^{\top}$ comprise a separate species, originally described as Alteromonas tetraodonis, whereas strain A-M belongs to the species Pseudoalteromonas haloplanktis. Based on phenotypic and chemotaxonomic data, genomic fingerprint patterns, DNA-DNA hybridization data and phylogenetic analysis of 165 rRNA, it is proposed that the species Alteromonas tetraodonis be retrieved and recognized as Pseudoalteromonas tetraodonis comb. nov. (type strain IAM $14160^{\top}=$ KMM $^{458}{ }^{\top}$ ).

Keywords: retrieval, Alteromonas tetraodonis, Pseudoalteromonas haloplanktis subsp. tetraodonis, Pseudoalteromonas tetraodonis

\section{INTRODUCTION}

The genus Pseudoalteromonas Gauthier et al. 1995 currently comprises 17 validly described species originating from the Alteromonas haloplanktis rRNA branch (Van Landschoot \& De Ley, 1983) of the former genus Alteromonas Baumann et al. 1972

\footnotetext{
†Present address: Swinburne University of Technology, IRIS, 533-545 Burwood Road, Hawthorn, Melbourne, Victoria 3122, Australia.

The GenBank accession numbers for the 16S rDNA sequences of Pseudoalteromonas tetraodonis $\mathrm{KMM} 458^{\top}$ and strain IAM $14160^{\top}$ are AF214729 and AF214730, respectively.
}

(Baumann et al., 1984; Gauthier \& Breittmayer, 1992). The type species of the genus Pseudoalteromonas is Pseudoalteromonas haloplanktis, which includes two subspecies, P. haloplanktis subsp. haloplanktis and $P$. haloplanktis subsp. tetraodonis. The latter was described as Alteromonas tetraodonis Simidu et al. 1990 to accommodate one of four marine bacterial isolates, strain $\mathrm{GFC}^{\mathrm{T}}$, that produces tetrodotoxin (Simidu et $a l ., 1990)$. This bacterium was isolated from the surface slime of a puffer fish (Fugu poecilonotus) shown to produce tetrodotoxin in association with the animals. A few years later, on the basis of DNA-DNA hybridization data, it was found that $A$. tetraodonis 
Simidu et al. 1990 should be recognized as a junior subjective synonym of $A$. haloplanktis (ZoBell and Upham 1944) Reichelt and Baumann 1973 (Baumann et al., 1984; Akagawa-Matsushita et al., 1993). At present, and in accordance with results of phylogenetic and biochemical analyses and the level of genomic DNA relatedness, this bacterial taxon is recognized as P. haloplanktis subsp. tetraodonis (Simidu et al. 1990) Gauthier et al. 1995.

During the last decade, bacterial isolates in the Collection of Marine Micro-organisms, Vladivostok, Russia, that are related to Alteromonas have been subjected to extensive taxonomic investigation. Shortly after publication of the article describing the new species Alteromonas tetraodonis, strain $\mathrm{GFC}^{\mathrm{T}}$ was subjected to DNA-DNA hybridization experiments to clarify the taxonomic position of the newly isolated bacteria. In 1991, K. Kita-Tsukamoto, on behalf of U. Simidu, kindly provided strain $\mathrm{GFC}^{\mathrm{T}}$, designated A. tetraodonis IAM $14160^{\mathrm{T}}$, and deposited it in our laboratory as strain KMM $458^{\mathrm{T}}$ (KMM; Collection of Marine Micro-organisms, Pacific Institute of Bioorganic Chemistry). Results of DNA-DNA hybridization studies disagreed with those published by Akagawa-Matsushita et al. (1993). After consultation with M. Akagawa-Matsushita, DNA-DNA hybridization experiments were repeated using strains $P$. haloplanktis subsp. haloplanktis IAM $12915^{\mathrm{T}}$, P. haloplanktis subsp. tetraodonis A-M (= KMM 3660), kindly provided by M. Akagawa-Matshushita, $P$. haloplanktis subsp. tetraodonis IAM $14160^{\mathrm{T}}$ from the Collection of the Institute of Molecular and Cellular Biosciences (formerly Institute of Applied Microbiology), Japan, and strain KMM $458^{\mathrm{T}}$ (formerly A. tetraodonis and provided by U. Simidu). Results showed that strains KMM $458^{\mathrm{T}}$ and IAM $14160^{\mathrm{T}}$ are identical and should be considered as a separate species, as described originally by Simidu et al. (1990). A polyphasic taxonomy study, including phenotypic, biochemical and genomic characteristics, together with phylogenetic study of the strains, was undertaken. Results given here have led to the conclusion that the species initially described as Alteromonas tetraodonis (Simidu et al., 1990) is indeed a species separate from $P$. haloplanktis and should be retrieved as Pseudoalteromonas tetraodonis comb. nov.

\section{METHODS}

Bacterial strains. The strains employed in this study are as follows: P. haloplanktis subsp. haloplanktis IAM $12915^{\mathrm{T}}$ $\left(=\right.$ ATCC $\left.14393^{\mathrm{T}}\right) ;$ P. haloplanktis subsp. tetraodonis IAM $14160^{\mathrm{T}}$; P. haloplanktis subsp. tetraodonis A-M (= KMM 3660), obtained from M. Akagawa-Matsushita; strain KMM $458^{\mathrm{T}}$ ( = IAM $14160^{\mathrm{T}}$ ), originally provided in 1991 by K. Kita-Tsukamoto, on behalf of U. Simidu, as Alteromonas tetraodonis IAM $14160^{\mathrm{T}}$; Pseudoalteromonas atlantica IAM $12376^{\mathrm{T}}$; and Pseudoalteromonas carrageenovora IAM $12662^{\mathrm{T}}$. The strains were grown at $25^{\circ} \mathrm{C}$ on Marine Agar 2216 (Difco) and stored frozen at $-80^{\circ} \mathrm{C}$ in Marine Broth (Difco) supplemented with $30 \%$ (v/v) glycerol.
Phenotypic analysis. Unless otherwise indicated, the phenotypic properties employed to characterize Alteromonas and related species were obtained using procedures described by Baumann et al. (1972, 1984) and Smibert \& Krieg (1994). Tests for utilization of various organic substrates (Table 1) as sole carbon sources, at concentrations of $0 \cdot 1 \%(\mathrm{w} / \mathrm{v})$, were performed as described elsewhere (Ivanova et al., 1996).

Sensitivity to antibiotics was tested by the disc-diffusion method using Marine Agar 2216 and discs impregnated with the following antibiotics: kanamycin $(30 \mu \mathrm{g})$; ampicillin $(10 \mu \mathrm{g})$; benzylpenicillin $(10 \mu \mathrm{g})$; streptomycin $(10 \mu \mathrm{g})$; erythromycin $(15 \mu \mathrm{g})$; gentamicin $(10 \mu \mathrm{g})$; oxacillin $(20 \mu \mathrm{g})$; lincomycin $(15 \mu \mathrm{g})$; carbenicillin $(25 \mu \mathrm{g})$; vancomycin $(30 \mu \mathrm{g})$; tetracycline $(30 \mu \mathrm{g})$; oleandomycin $(15 \mu \mathrm{g})$; and $\mathrm{O} / 129(150 \mu \mathrm{g})$.

Lipid analysis. Lipids were extracted from wet cells, according to the method of Bligh \& Dyer (1953). Polar lipids were subjected to two-dimensional TLC using $10 \times$ $10 \mathrm{~cm}$ silica gel plates (KSK). Following development in chloroform/methanol/ammonium hydrate/benzene $(65: 30: 6: 10)$ (first dimension) and chloroform/methanol/ acetone/acetic acid/benzene/water (70:30:5:4:1:10) (second dimension), lipids were detected on chromatograms by spraying with both a non-specific reagent ( $50 \%$ sulfuric acid in methanol and heating at $180{ }^{\circ} \mathrm{C}$ ) and specific reagents (ninhydrin and Dragendorff's reagent). Quantification of phospholipids on two-dimensional chromatograms was done using the method of Vaskovsky et al. (1975).

Fatty acid methyl ester analysis. Analysis of fatty acid methyl esters was performed by GLC, as described previously by Svetashev et al. (1995).

Serology. ELISA was performed, according to the methods of Voller et al. (1979), as described elsewhere (Ivanova et al., 1998). The level of antigen relatedness was estimated, as described by Conway de Macario et al. (1982), as the mean value of three independent experiments.

Genetic analysis. DNA was isolated according to the method of Marmur (1961). DNA $\mathrm{G}+\mathrm{C}$ content (mol\%) was determined by the thermal denaturation methods of Marmur \& Doty (1962) and Owen et al. (1969). DNA-DNA hybridization was performed spectrophotometrically and initial renaturation rates were recorded as described by De Ley et al. (1970).

Genomic fingerprints: primers and PCR conditions. PCR genomic fingerprinting was carried out using specific primers and conditions as follows. REP-directed PCR (Louws et al., 1994): REP1R-I, 5'-IIIICGICGICATCIGGC-3'; REP2-I, 5'-ICGICTTATCIGGCCTAC-3'. ERIC-directed PCR (Judd et al., 1993): ERIC 1 (reverse), 5'-ATGTAAGCTCCTGGGGATTCAC-3'; ERIC 2 (forward): 5'-AAGTAAGTGACTGGGGTGAGCG-3'. BOX-directed PCR (Versalovic et al., 1991; Louws et al., 1994): 5'-CTACGGCAAGGCGACGCTGACG-3'. PCRs were performed using the following programs: one initial cycle at $95^{\circ} \mathrm{C}$ for 7 min, 35 cycles of denaturation at $94^{\circ} \mathrm{C}$ for $1 \mathrm{~min}$, annealing at 44,52 or $53{ }^{\circ} \mathrm{C}$ for 1 min with REP, ERIC or BOX primers, respectively, and extension at $65^{\circ} \mathrm{C}$ for $10 \mathrm{~min}$, with a single final extension cycle at $65^{\circ} \mathrm{C}$ for $20 \mathrm{~min}$ for REP, ERIC and BOX primers, and a final soak at $4{ }^{\circ} \mathrm{C}$. PCR products were separated by horizontal electrophoresis on $2.2 \%$ agarose gels, stained with SYBR Green I (FMC Bioproducts) and visualized by scanning at $500 \mathrm{~nm}$ in a Fluorimager scanner (Molecular Dynamics). To examine 
Table 1. Phenotypic data for $P$. haloplanktis subsp. haloplanktis and strains of $P$. haloplanktis subsp. tetraodonis

All strains studied produced gelatinase and lipase, did not produce alginase or agarase, did not grow at $41^{\circ} \mathrm{C}$ and utilized succinate and fumarate. +, Positive; -, negative; ND, no data available; D, 11-89\% of strains positive; v, variable.

\begin{tabular}{|c|c|c|c|c|c|c|}
\hline \multirow[t]{2}{*}{ Characteristic } & \multicolumn{3}{|c|}{ P. haloplanktis subsp. haloplanktis IAM $12915^{\mathrm{T}}$} & \multicolumn{3}{|c|}{ P. haloplanktis subsp. tetraodonis IAM $14160^{\mathrm{T}}$} \\
\hline & $\begin{array}{c}\text { Baumann } \\
\text { et al. (1984) }\end{array}$ & $\begin{array}{c}\text { Akagawa-Matsushita } \\
\text { et al. (1993) }\end{array}$ & This study & $\begin{array}{l}\text { Akagawa-Matsushita } \\
\text { et al. (1993) }\end{array}$ & $\begin{array}{c}\text { Simidu } \\
\text { et al. }(1990)\end{array}$ & This study \\
\hline \multicolumn{7}{|l|}{ Production of: } \\
\hline Amylase & $\mathrm{D}$ & - & - & - & - & - \\
\hline Chitinase & D & ND & - & ND & - & - \\
\hline \multicolumn{7}{|l|}{ Growth at: } \\
\hline $4^{\circ} \mathrm{C}$ & - & $+^{*}$ & - & $+^{*}$ & + & + \\
\hline $35^{\circ} \mathrm{C}$ & $\mathrm{D}$ & + & + & + & + & + \\
\hline \multicolumn{7}{|l|}{ Utilization of: } \\
\hline $\begin{array}{l}\text { D-Glucose, pyruvate, } \\
\text { ethanol, acetate }\end{array}$ & + & ND & + & ND & + & + \\
\hline D-Mannose & + & - & + & - & + & - \\
\hline D-Fructose & $\mathrm{D}$ & + & + & - & + & - \\
\hline Sucrose & + & - & + & + & + & + \\
\hline Trehalose & D & - & - & + & + & - \\
\hline Maltose & + & $\mathrm{ND}$ & + & ND & + & + \\
\hline Cellobiose & - & + & - & + & + & - \\
\hline $\begin{array}{l}\text { Lactose, D-ribose, D-xylose, } \\
\text { D-arabinose, rhamnose, } \\
\text { gluconate, salicin, } \\
\text { ketoglutarate, glycerol }\end{array}$ & - & - & - & - & + & - \\
\hline D-Galactose & $\mathrm{D}$ & - & $\mathrm{v}$ & - & + & + \\
\hline Propionate & + & ND & + & ND & + & ND \\
\hline Butyrate, valerate & $\mathrm{D}$ & + & $\mathrm{v}$ & + & + & + \\
\hline Caproate & - & + & - & + & - & + \\
\hline DL-Lactate & ND & - & - & - & + & + \\
\hline Citrate & + & - & + & - & - & + \\
\hline Aconitate & + & - & + & - & + & + \\
\hline Caprylate & D & - & v & - & ND & - \\
\hline D-Malate & - & - & - & + & - & - \\
\hline Mannitol & $\mathrm{D}$ & - & $\mathrm{v}$ & - & + & - \\
\hline D-Sorbitol & - & ND & - & ND & + & - \\
\hline$p$-Hydroxybenzoate & - & - & - & - & + & ND \\
\hline L-Alanine & - & ND & + & $\mathrm{ND}$ & + & + \\
\hline L-Threonine & - & ND & - & ND & + & - \\
\hline Aspartate & $\mathrm{D}$ & ND & ND & ND & - & - \\
\hline Glutamate & $\mathrm{D}$ & ND & + & ND & + & + \\
\hline L-Lysine & - & - & - & + & + & - \\
\hline L-Arginine & $\mathrm{D}$ & - & - & + & + & - \\
\hline L-Ornithine & - & - & - & - & + & - \\
\hline L-Histidine & $\mathrm{D}$ & ND & + & ND & + & - \\
\hline L-Proline & $\mathrm{D}$ & ND & + & ND & + & - \\
\hline L-Tyrosine & + & - & + & - & + & + \\
\hline L-Phenylalanine & - & - & - & - & + & - \\
\hline
\end{tabular}

* Growth tested at $5{ }^{\circ} \mathrm{C}$.

the reproducibility of the results, the ERIC and BOX PCRs were repeated at least twice.

DNA amplification and sequencing. Bacterial DNAs for PCR were prepared using the Promega Wizard genomic DNA extraction kit according to the instruction manual. DNA templates (100 ng) were used in PCR to amplify smallsubunit rRNA genes, as described previously by Sawabe et al. (1998a, b). PCR conditions were as follows: an initial denaturation step at $94{ }^{\circ} \mathrm{C}$ for $180 \mathrm{~s}$, an annealing step at $55^{\circ} \mathrm{C}$ for $60 \mathrm{~s}$ and an extension step at $72{ }^{\circ} \mathrm{C}$ for $90 \mathrm{~s}$. The thermal profile then consisted of 30 cycles. The amplification primers used in this study gave a $1.5 \mathrm{~kb}$ PCR product and corresponded to positions 25-1521 of the Escherichia coli sequence. The PCR products were purified using a Promega Wizard PCR preps DNA purification kit and sequenced directly by using a Taq FS dye terminator sequencing kit (ABI) and the protocol recommended by the manufacturer. DNA sequencing was performed with an Applied Bio- systems model $373 \mathrm{~S}$ automated sequencer. Nine sequencing primers were used (Sawabe et al., 1998a).

Phylogenetic analysis. Sequences were aligned and studied using a set of programs developed by R. Christen. In all phylogenetic analyses, the sequences determined in this study and small-subunit rDNA sequences obtained from the EMBL database were used. Domains used to construct the dendrogram shown in Fig. 2 were regions of the smallsubunit rDNA sequences available for all sequences and excluding positions likely to show homoplasy: positions 101-181, 219-837, 850-1133, 1138-1205 (E. coli smallsubunit rDNA sequence J01695 numbering). Phylogenetic analyses were performed using three different methods: distances were calculated using Kimura's two-parameter correction and a modified neighbour-joining method, BIONJ (Gascuel, 1997), maximum-likelihood (options QFYG, fastDNAml program; Olsen et al., 1994) and maximumparsimony (PHYLIP, Phylogeny Inference Package, version 
3.5c; distributed by J. Felsenstein, Department of Genetics, University of Washington, Seattle, WA, USA). The robustness of each topology was checked using the neighbourjoining method and 100 bootstrap replications. Trees were drawn using the NJPLOT program for the Macintosh (M. Gouy, CNRS URA 243, Université Claude Bernard, Lyon, France).

\section{RESULTS AND DISCUSSION}

The bacterial strain $\mathrm{GFC}^{\mathrm{T}}\left(=\mathrm{KMM} 458^{\mathrm{T}}=\mathrm{IAM}\right.$ $14160^{\mathrm{T}}$ ), described originally as Alteromonas tetraodonis, had all the features characteristic for the genus Pseudoalteromonas (formerly an rRNA cluster of Alteromonas haloplanktis). The strain was motile by means of a single flagellum. It was a chemo-organotroph, with a respiratory metabolism. It did not form endospores or accumulate polyhydroxybutyrate as an intracellular reserve product. It did not possess arginine dihydrolase and was oxidase- and catalase- positive. It required $\mathrm{Na}^{+}$or sea water for growth; good growth was observed in media containing $1-7 \% \mathrm{NaCl}$. The temperature range for growth was $4-35^{\circ} \mathrm{C}$, with an optimum between 25 and $30^{\circ} \mathrm{C}$. No growth was detected at $40^{\circ} \mathrm{C}$. The $\mathrm{pH}$ range for growth was $5 \cdot 5-9 \cdot 5$, with optimum growth at $\mathrm{pH} 7 \cdot 5-8 \cdot 0$. Amylase, agarase, chitinase and alginase were not produced. Tween 80, gelatin and DNA were decomposed. Many of these characteristics, and others listed in Table 1, are similar for $P$. haloplanktis subsp. haloplanktis, $P$. haloplanktis subsp. tetraodonis and strains A-M and KMM $458^{\mathrm{T}}$ (= IAM $\left.14160^{\mathrm{T}}\right)$. On the other hand, differences in carbohydrate utilization were noted when comparing related data published by other investigators. Strain KMM $458^{\mathrm{T}}$ utilized DL-lactate, caproate, valerate and butyrate, whereas $P$. haloplanktis subsp. haloplanktis did not utilize these compounds. In contrast, strain KMM $458^{\mathrm{T}}$ did not utilize D-mannose, D-fructose, mannitol, L-histidine or

Table 2. Fatty acid composition of $P$. haloplanktis and $P$. tetraodonis

Data were from Svetashev et al. (1995) and this study.

\begin{tabular}{|c|c|c|c|}
\hline Fatty acid & P. haloplanktis IAM $12915^{\mathrm{T}}$ & P. haloplanktis A-M & P. tetraodonis KMM $458^{\mathrm{T}}\left(=\right.$ IAM $\left.14160^{\mathrm{T}}\right)$ \\
\hline $11: 03-\mathrm{OH}$ & $0 \cdot 3$ & $0 \cdot 24$ & $0 \cdot 4$ \\
\hline $12: 03-\mathrm{OH}$ & $1 \cdot 9$ & $1 \cdot 11$ & $0 \cdot 9$ \\
\hline $12: 0$ & $2 \cdot 0$ & $2 \cdot 12$ & $1 \cdot 5$ \\
\hline $12: 1$ & $0 \cdot 3$ & $0 \cdot 54$ & $0 \cdot 3$ \\
\hline i13:0 & $0 \cdot 1$ & $0 \cdot 00$ & $0 \cdot 0$ \\
\hline $13: 0$ & $0 \cdot 2$ & $0 \cdot 26$ & $0 \cdot 5$ \\
\hline $13: 1$ & $0 \cdot 3$ & $0 \cdot 26$ & $0 \cdot 5$ \\
\hline $\mathrm{i} 14: 0$ & $0 \cdot 0$ & $0 \cdot 15$ & $0 \cdot 1$ \\
\hline $14: 0$ & $2 \cdot 0$ & $1 \cdot 62$ & $2 \cdot 0$ \\
\hline $14: 1(n-7)$ & $0 \cdot 6$ & $1 \cdot 13$ & $1 \cdot 2$ \\
\hline i15:0 & $0 \cdot 0$ & $0 \cdot 11$ & $0 \cdot 0$ \\
\hline a $15: 0$ & $0 \cdot 2$ & $0 \cdot 58$ & $0 \cdot 4$ \\
\hline $15: 0$ & $3 \cdot 3$ & $3 \cdot 47$ & $8 \cdot 0$ \\
\hline $15: 1(n-8)$ & $2 \cdot 3$ & $2 \cdot 80$ & $6 \cdot 3$ \\
\hline $15: 1(n-6)$ & $0 \cdot 2$ & $0 \cdot 36$ & $0 \cdot 6$ \\
\hline i16:0 & $0 \cdot 2$ & $2 \cdot 52$ & $1 \cdot 4$ \\
\hline $16: 0$ & $30 \cdot 1$ & $23 \cdot 10$ & $18 \cdot 2$ \\
\hline $16: 1(n-9)$ & $0 \cdot 0$ & $0 \cdot 82$ & $0 \cdot 0$ \\
\hline $16: 1(n-7)$ & $40 \cdot 5$ & $38 \cdot 37$ & $35 \cdot 0$ \\
\hline $16: 1(n-5)$ & $0 \cdot 0$ & $0 \cdot 39$ & $0 \cdot 2$ \\
\hline i17:0 & $0 \cdot 0$ & 0.68 & $0 \cdot 3$ \\
\hline a17:0 & $0 \cdot 0$ & $1 \cdot 15$ & $0 \cdot 6$ \\
\hline $17: 0$ & $3 \cdot 9$ & $3 \cdot 76$ & $5 \cdot 5$ \\
\hline $17: 1(\mathrm{n}-8)$ & $6 \cdot 0$ & $6 \cdot 25$ & $10 \cdot 7$ \\
\hline $17: 1(\mathrm{n}-6)$ & $0 \cdot 2$ & 0.52 & $0 \cdot 8$ \\
\hline i18:0 & $0 \cdot 0$ & $0 \cdot 49$ & $0 \cdot 2$ \\
\hline $18: 0$ & 1.9 & $1 \cdot 30$ & 0.6 \\
\hline $18: 1(n-11)$ & $0 \cdot 1$ & $0 \cdot 34$ & $0 \cdot 4$ \\
\hline $18: 1(n-9)$ & $0 \cdot 2$ & $0 \cdot 11$ & $0 \cdot 2$ \\
\hline $18: 1(n-7)$ & $2 \cdot 4$ & $4 \cdot 28$ & $2 \cdot 5$ \\
\hline $19: 1$ & $0 \cdot 2$ & $0 \cdot 28$ & $0 \cdot 2$ \\
\hline Unidentified fatty acid & - & $0 \cdot 56$ & - \\
\hline Total & $99 \cdot 5$ & $99 \cdot 67$ & $99 \cdot 6$ \\
\hline
\end{tabular}



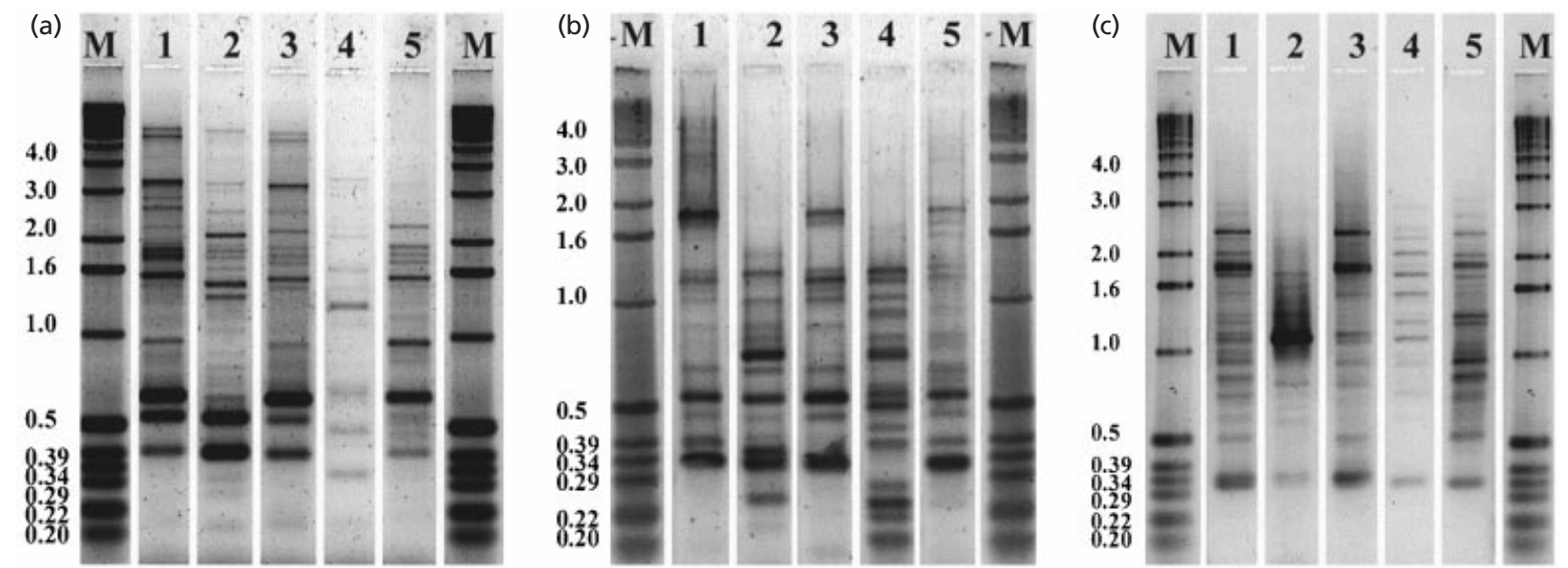

Fig. 1. Comparative genomic fingerprinting of some Pseudoalteromonas species. REP (a), ERIC (b) and BOX (c) PCR patterns are shown. The fingerprints are as follows: $M, 1 \mathrm{~kb}$ ladder (Gibco-BRL); 1 , $P$. tetraodonis IAM $14160^{\top}$; $2, P$. haloplanktis IAM $12915^{\top}$; 3, P. tetraodonis KMM 458 ${ }^{\top}$; 4, P. atlantica IAM 12376 ${ }^{\top}$; and 5, P. carrageenovora IAM $12622^{\top}$.

Table 3. DNA relatedness of $P$. haloplanktis and $P$. tetraodonis

\begin{tabular}{|c|c|c|c|}
\hline \multirow[t]{2}{*}{ Taxon } & \multirow{2}{*}{$G+C$ content $(\mathbf{m o l} \%)$} & \multicolumn{2}{|c|}{ DNA relatedness (\%) } \\
\hline & & P. haloplanktis IAM $12915^{\mathrm{T}}$ & P. tetraodonis IAM $14160^{\mathrm{T}}$ \\
\hline P. haloplanktis IAM $12915^{\mathrm{T}}$ & $42 \cdot 2$ & 100 & - \\
\hline P. haloplanktis A-M & $41 \cdot 3$ & 83 & 32 \\
\hline P. tetraodonis $\mathrm{KMM} 458^{\mathrm{T}}$ & $41 \cdot 5$ & 49 & 99 \\
\hline P. tetraodonis IAM $14160^{\mathrm{T}}$ & $41 \cdot 8$ & 48 & 100 \\
\hline
\end{tabular}

L-proline (Table 1). The strain was susceptible to benzylpenicillin, carbenicillin, vancomycin and tetracycline.

Cellular fatty acids of strains A-M and KMM $458^{\mathrm{T}}$ were characteristic for Pseudoalteromonas species (Table 2 ) and the dominant fatty acids were as follows: $16: 1(n-7), 16: 0,17: 1(n-8), 17: 0$ and 18:1(n-8). However, the fatty acid profiles of $P$. haloplanktis subsp. haloplanktis IAM $12915^{\mathrm{T}}$ and strain A-M were similar and they contrasted with that of strain KMM $458^{\mathrm{T}}$. For example, the amounts of 15:0, 15:1(n-8), 17:0 and $17: 1(n-8)$ fatty acids for the latter strain were almost twice those in the other two strains.

Phospholipids were a significant component of the polar lipids (ca. 80-85\%); the phospholipid composition was generally the same for all strains included in this study. Phosphatidyl ethanolamine and phosphatidyl glycerol were the major components: 73.2 and $23 \%$ for $P$. haloplanktis subsp. haloplanktis IAM $12915^{\mathrm{T}}, 75 \cdot 1$ and $23.7 \%$ for $P$. haloplanktis subsp. tetraodonis IAM $14160^{\mathrm{T}}$ and 71.7 and $21.7 \%$ for strain KMM $458^{\mathrm{T}}$, respectively. The concentrations of the minor phospholipids varied slightly. In the three strains above, levels of bis-phosphatidic acid were $1 \cdot 8$, $2 \cdot 2$ and $1.7 \%$, those of phosphatidic acid were $0 \cdot 3,0 \cdot 7$ and $1 \cdot 2 \%$ and those of $l y s o$-phosphatidyl ethanolamine were $1.9,0.7$ and $0.6 \%$, respectively. Unidentified phospholipids $(0.6 \%)$ were present in the lipid fractions of $P$. haloplanktis subsp. tetraodonis IAM $14160^{\mathrm{T}}$ and $\mathrm{KMM} 458^{\mathrm{T}}$. Cardiolipin and glycolipids were not detected.

Genomic fingerprinting patterns obtained using primers corresponding to the REP, ERIC and BOX elements of $P$. haloplanktis subsp. tetraodonis IAM $14160^{\mathrm{T}}$ and KMM $458^{\mathrm{T}}$ were identical, whereas those of $P$. haloplanktis subsp. haloplanktis IAM $12915^{\mathrm{T}}$ were different. Since a dispersion of repetitive sequences in the bacterial genome reflects a strainspecific characteristic, the identity of the genomic profiles is interpreted as identity of strains IAM $14160^{\mathrm{T}}$ and KMM 458 ${ }^{\mathrm{T}}$ (Fig. 1).

Results of DNA-DNA hybridizations showed that strains KMM 458 ${ }^{\mathrm{T}}$ and IAM $14160^{\mathrm{T}}$ are $99 \%$ related to each other, but only $48-49 \%$ related to the type strain, $P$. haloplanktis subsp. haloplanktis IAM $12915^{\mathrm{T}}$. Strain A-M showed $83 \%$ genetic similarity to $P$. haloplanktis subsp. haloplanktis IAM $12915^{\mathrm{T}}$ and $32 \%$ to KMM $458^{\mathrm{T}}$ (Table 3 ). Thus, the two strains KMM $458^{\mathrm{T}}$ and IAM $14160^{\mathrm{T}}$ represent a distinct species, originally described as Alteromonas tetraodonis by 


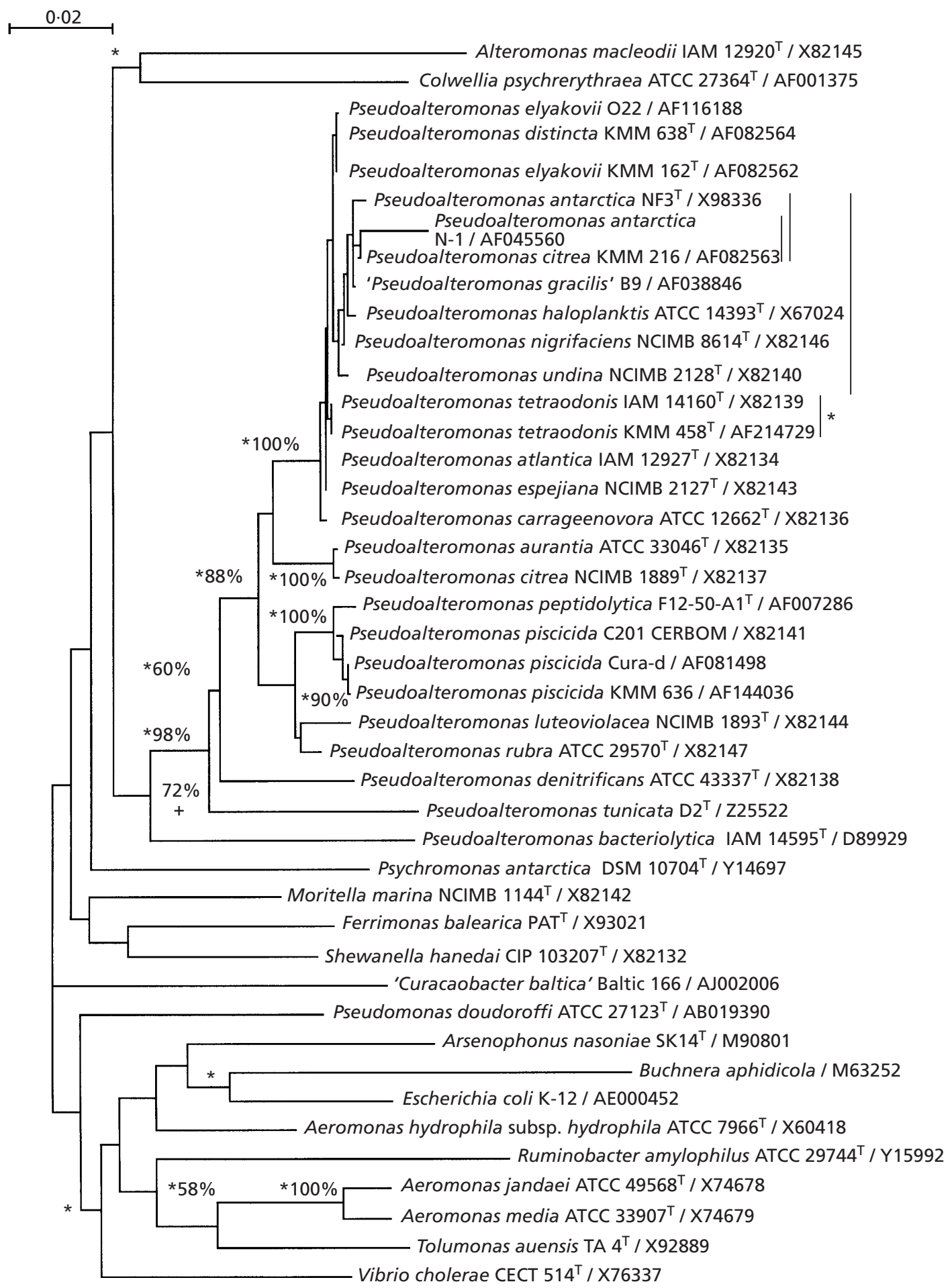

Fig. 2. Unrooted tree obtained using the neighbour-joining algorithm and Kimura's two-parameter correction for distance calculations. Branches also obtained in the maximum-likelihood analysis are indicated by asterisks $(P<0.01)$. + , Branches also found in maximum-likelihood and parsimony analysis; bootstrap percentages retrieved in 500 replicons bootstrap analysis using Kimura's two-parameter analysis are shown at the nodes. Bar, 0.02 accumulated changes per nucleotide.

Simidu et al. (1990), which is consistent with the criteria cited by Wayne et al. (1987). In contrast, it is concluded that strain A-M belongs to P. haloplanktis and, on the basis of its high DNA-DNA hybridization value with strain IAM $12915^{\mathrm{T}}(83 \%)$, that it does not merit subspecies status. Results of the DNA-DNA 
hybridization experiments were supported by serological data obtained using polyclonal antibodies to cell surface determinants. Antiserum to P. haloplanktis subsp. haloplanktis IAM $12915^{\mathrm{T}}$ did not cross-react with surface antigens of KMM $458^{\mathrm{T}}$, even though it showed $50 \%$ surface antigen similarity to strain IAM $14160^{\mathrm{T}}$.

In order to clarify the taxonomic affiliation of $P$. haloplanktis subsp. tetraodonis IAM $14160^{\mathrm{T}}$ and $\mathrm{KMM} 458^{\mathrm{T}}$ at the genus level, the $16 \mathrm{~S}$ rDNA sequences were aligned by comparison to a database containing about 10000 already aligned eubacterial small-subunit rDNA sequences. The results of broad phylogenetic analyses showed clearly that the strains studied belonged to the $\gamma$-Proteobacteria of the Bacteria (data not shown) and, more precisely, to the $\gamma-3$ subgroup. More detailed analyses showed that these bacteria were included in the genus Pseudoalteromonas and formed a cluster with $P$. haloplanktis, $P$. nigrifaciens, ' $P$. gracilis', $P$. citrea KMM 216 and $P$. antarctica. Sequence similarities between $P$. haloplanktis subsp. haloplanktis ATCC $14393^{\mathrm{T}}$ and both P. haloplanktis subsp. tetraodonis IAM $14610^{\mathrm{T}}$ and KMM $458^{\mathrm{T}}$ were $99.9 \%$ (Fig. 2). Rather low DNA homology values, about $50 \%$, against $P$. haloplanktis subsp. haloplanktis have enabled recognition of $P$. haloplanktis subsp. tetraodonis and $P$. haloplanktis subsp. haloplanktis as separate species of the genus Pseudoalteromonas. Pseudoalteromonas tetraodonis comb. nov. and an emended species Pseudoalteromonas haloplanktis are proposed.

\section{Description of Pseudoalteromonas tetraodonis comb. nov.}

Basonym Pseudoalteromonas haloplanktis subsp. tetraodonis (Simidu et al. 1990) Gauthier et al. 1995.

The description of Pseudoalteromonas tetraodonis comb. nov. is identical to that given by Simidu et al. (1990), with some additional characteristics, including growth in media containing $1-10 \% \mathrm{NaCl}$, growth at pH 5.5-9.5, with optimum growth at $7 \cdot 5-8 \cdot 0$, and utilization of D-glucose, sucrose, D-maltose, D-galactose, DL-lactate, caproate, valerate, butyrate, citrate, fumarate, succinate, caprylate, glutamate, acetate, pyruvate, ethanol and L-tyrosine. It does not utilize Dmannose, D-fructose, mannitol, L-histidine, L-proline or D-malate. It is susceptible to benzylpenicillin, carbenicillin, vancomycin and tetracycline. Cellular fatty acids include 16:1(n-7), 16:0, 17:1(n-8), 17:0 and $18: 1(\mathrm{n}-8)$. The $15: 0,15: 1(\mathrm{n}-8), 17: 0$ and $17: 1(\mathrm{n}-$ 8) fatty acids are minor components. The major phospholipids, phosphatidyl ethanolamine and phosphatidyl glycerol, constitute 75.1 and $23.7 \%$ of the total polar lipids. Cardiolipin and glycolipids are absent. The DNA G $+\mathrm{C}$ content of $P$. tetraodonis is $41.5 \mathrm{~mol} \%$ (determined by thermal denaturation). The type strain is $\mathrm{GFC}^{\mathrm{T}}\left(=\mathrm{KMM} 458^{\mathrm{T}}=\mathrm{IAM} 14160^{\mathrm{T}}\right)$, isolated from the surface slime of a puffer fish (Fugu poecilonotus).

\section{Emended description of Pseudoalteromonas haloplanktis}

The description of Pseudoalteromonas haloplanktis is identical to that of Alteromonas haloplanktis given by ZoBell \& Upham (1944), with some additional characteristics. It is resistant to benzylpenicillin, vancomycin and tetracycline. Cellular fatty acids include $16: 1(\mathrm{n}-7)$, $16: 0,17: 1(\mathrm{n}-8), 17: 0$ and $18: 1(\mathrm{n}-8)$. The $15: 0,15: 1(\mathrm{n}-$ 8), $17: 0$ and $17: 1(\mathrm{n}-8)$ fatty acids are minor components. The major phospholipids, phosphatidyl ethanolamine and phosphatidyl glycerol, constitute $73 \cdot 2$ and $23.0 \%$ of the total polar lipids. Cardiolipin and glycolipids are absent. The type strain is IAM $12915^{\mathrm{T}}$ (=ATCC $14393^{\mathrm{T}}$ ). Strain A-M (= KMM 3660), assigned previously to $P$. haloplanktis subsp. tetraodonis, is a strain of $P$. haloplanktis.

\section{ACKNOWLEDGEMENTS}

This study was supported by a short-term UNESCO Fellowship, by funds from the Russian Fund for Basic Research 99-04-48017 and by a grant of the State Committee for Science and Technologies of the Russian Federation, 99-03-19. The authors also gratefully acknowledge the Fundação de Amparo à Pesquisa do Estado de São Paulo for postdoctoral fellowship support provided to M.H.M. and G.R.M.

\section{REFERENCES}

Akagawa-Matsushita, M., Koga, Y. \& Yamasato, K. (1993). DNA relatedness among nonpigmented species of Alteromonas and synonymy of Alteromonas haloplanktis (ZoBell and Upham 1944) Reichelt and Baumann 1973 and Alteromonas tetraodonis Simidu et al. 1990. Int J Syst Bacteriol 43, 500-503.

Baumann, L., Baumann, P., Mandel, M. \& Allen, R. D. (1972). Taxonomy of aerobic marine eubacteria. J Bacteriol 110, 402-429.

Baumann, P., Gauthier, M. J. \& Baumann, L. (1984). Genus Alteromonas Baumann, Baumann, Mandel and Allen 1972, $418^{\mathrm{AL}}$. In Bergey's Manual of Systematic Bacteriology, vol. 1, pp. 343-352. Edited by N. R. Krieg \& J. G. Holt. Baltimore: Williams \& Wilkins.

Bligh, E. G. \& Dyer, W. J. (1953). A rapid method of lipid extraction and purification. Can J Biochem Physiol 7, 911-915.

Conway de Macario, E., Macario, A. J. L. \& Wolin, M. J. (1982). Specific antisera and immunological procedures for characterization of methanogenic bacteria. J Bacteriol 149, 320-328.

De Ley, J., Cattoir, H. \& Reynaerts, A. (1970). The quantitative measurement of DNA hybridization from renaturation rates. Eur J Biochem 12, 133-142.

Gascuel, O. (1997). BIONJ: an improved version of the NJ algorithm based on a simple model of sequence data. Mol Biol Evol 14, 685-695.

Gauthier, M. J. \& Breittmayer, V. A. (1992). The genera Alteromonas and Marinomonas. In The Prokaryotes, pp. 3046-3070. Edited by A. Balows, H. G. Trüper, M. Dworkin, W. Harder \& K.-H. Schleifer. New York: Springer.

Gauthier, G., Gauthier, M. \& Christen, R. (1995). Phylogenetic analysis of the genera Alteromonas, Shewanella, and Moritella using genes coding for small-subunit rRNA sequences and division of the genus Alteromonas into two genera, Alteromonas 
(emended) and Pseudoalteromonas gen. nov., and proposal of twelve new species combinations. Int $J$ Syst Bacteriol 45, 755-761.

Ivanova, E. P., Kiprianova, E. A., Mikhailov, V. V., Levanova, G. F., Garagulya, A. D., Gorshkova, N. M., Yumoto, N. \& Yoshikawa, S. (1996). Characterization and identification of marine Alteromonas nigrifaciens strains and emendation of the description. Int J Syst Bacteriol 46, 223-228.

Ivanova, E. P., Kiprianova, E. A., Mikhailov, V. V. \& 8 other authors (1998). Phenotypic diversity of Pseudoalteromonas citrea from different marine habitats and emendation of the description. Int J Syst Bacteriol 48, 247-256.

Judd, A. K., Schneider, M., Sadowsky, M. J. \& de Bruijn, F. J. (1993). Use of repetitive sequences and the polymerase chain reaction technique to classify genetically related Bradyrhizobium japonicum serocluster 123 strains. Appl Environ Microbiol 59, 1702-1708.

Louws, F. J., Fulbright, D. W., Stephens, C. T. \& de Bruijn, F. J. (1994). Specific genomic fingerprints of phytopathogenic Xanthomonas and Pseudomonas pathovars and strains generated with repetitive sequences and PCR. Appl Environ Microbiol 60, 2286-2295.

Marmur, J. (1961). A procedure for the isolation of deoxyribonucleic acid from microorganisms. J Mol Biol 3, 208-218.

Marmur, J. \& Doty, P. (1962). Determination of the base composition of deoxyribonucleic acid from its thermal denaturation temperature. J Mol Biol 5, 109-118.

Olsen, G. J., Matsuda, H., Hagstrom, R. \& Overbeek, R. (1994). fastDNAml: a tool for construction of phylogenetic trees of DNA sequences using maximum likelihood. Comput Appl Biosci 10, 41-48.

Owen, R. J., Hill, L. R. \& Lapage, S. P. (1969). Determination of DNA base compositions from melting profiles in dilute buffers. Biopolymers 7, 503-516.

Sawabe, T., Sugimura, I., Ohtsuka, M., Nakano, K., Tajima, K., Ezura, Y. \& Christen, R. (1998a). Vibrio halioticoli sp. nov., a nonmotile alginolytic marine bacterium isolated from the gut of the abalone Haliotis discus hannai. Int J Syst Bacteriol 48, 573-580.
Sawabe, T., Makino, H., Tatsumi, M., Nakano, K., Tajima, K., Iqbal, M. M., Yumoto, I., Ezura, Y. \& Christen, R. (1998b). Pseudoalteromonas bacteriolytica sp. nov., a marine bacterium that is the causative agent of red spot disease of Laminaria japonica. Int J Syst Bacteriol 48, 769-774.

Simidu, U., Kita-Tsukamoto, K., Yasumoto, T. \& Yotsu, M. (1990). Taxonomy of four marine bacterial strains that produce tetrodotoxin. Int J Syst Bacteriol 40, 331-336.

Smibert, R. M. \& Krieg, N. R. (1994). Phenotypic characterization. In Methods for General and Molecular Bacteriology, pp. 607-654. Edited by F. Gerhardt. Washington, DC: American Society for Microbiology.

Svetashev, V. I., Vysotskii, M. V., Ivanova, E. P. \& Mikhailov, V. V. (1995). Cellular fatty acids of Alteromonas species. Syst Appl Microbiol 18, 37-43.

Van Landschoot, A. \& De Ley, J. (1983). Intra- and intergeneric similarities of the rRNA cistrons of Alteromonas, Marinomonas (gen. nov.) and some other Gram-negative bacteria. $J$ Gen Microbiol 129, 3057-3074.

Vaskovsky, V. E., Kostetsky, E. Y. \& Vasendin, I. M. (1975). A universal reagent for phospholipid analysis. J Chromatogr 114, 129-141.

Versalovic, J., Koeuth, T. \& Lupski, J. R. (1991). Distribution of repetitive DNA sequences in eubacteria and application to fingerprinting of bacterial genomes. Nucleic Acids Res 19, 6823-6831.

Voller, A., Bidwell, D. E. \& Bartlett, A. (1979). Setting up ELISA. In The Enzyme-linked Immunosorbent Assay (ELISA). A Guide with Abstracts of Microplate Applications, pp. 38-39. Guernsey: Dynatech Europe.

Wayne, L. G., Brenner, D. J., Colwell, R. R. \& 9 other authors (1987). Report of the ad hoc committee on reconciliation of approaches to bacterial systematics. Int J Syst Bacteriol 37, 463-464.

ZoBell, C. E. \& Upham, H. C. (1944). A list of marine bacteria including description of sixty new species. Bull Scripps Inst Oceanogr Univ Calif 5, 239-292. 